\title{
Dominasi Oligarki dan Ketidakhadiran Partai Politik Hijau di Indonesia
}

\section{Oligarchy Domination and The Absence of Green Political Party in Indonesia}

\author{
Luthfi Hasanal Bolqiah ${ }^{1}$, Riaty Raffiudin ${ }^{2}$ \\ 1.2 Program Pascasarjana Ilmu Politik, Fakultas Ilmu Sosial dan Ilmu Politik, Universitas Indonesia \\ luthfi.hasanalbolqiah@gmail.com,riatyraf@gmail.com
}

Diterima: 15 November 2020

Direvisi: 22 Desember 2020

Disetujui: 23 Desember 2020

DOI: 10.35967/njip.v19i2.112

\begin{abstract}
Abstrak: Kerusakan lingkungan dan dampaknya merupakan persoalan yang masih terus berlanjut di Indonesia serta belum cukup mampu untuk mendorong transformasi narasi politik hijau menjadi platform partai politik sebagaimana yang terjadi di negara lain. Literatur sebelumnya sering kali menggunakan kerangka liberalis dan menuntut kesadaran kolektif serta partisipasi masyarakat dalam mengawasi persoalan lingkungan, bukan urgensi keterwakilan politik hijau. Selain itu, perspektif konstitusional dan institusional juga terlampau idealis dan kurang memperhatikan kepentingan individu yang selalu mencari keuntungan. Tulisan ini berupaya untuk menganalisis penyebab dari persoalan lingkungan serta absennya keterwakilan narasi politik hijau dalam bentuk formal dengan menggunakan teori oligarki dan keterwakilan politik. Melalui analisa kualitatif deskriptif dengan metode wawancara dan studi literatur ditemukan: (1) narasi politik Hijau di Indonesia tersebar di berbagai janji kandidat dan partai politik menjelang pemilu, (2) konsentrasi pengelolaan dan penguasaan sumber daya alam merupakan sumber pendapatan oligarki yang terus dipertahankan, (3) keterlibatan oligarki dalam politik menghambat pertimbangan narasi politik hijau dalam proses pembuatan kebijakan, (4) ketidakhadiran platform partai politik hijau memberi keleluasaan terhadap dominasi oligarki, sedangkan (4) konsolidasi platform politik hijau juga terkendala faktor internal berupa pro dan kontra pendirian partai serta faktor eksternal seperti sistem kepartaian dan aturan-aturan pemilihan umum.
\end{abstract}

Kata Kunci: Dominasi Oligarki, Kerusakan Lingkungan, Keterwakilan, Partai Politik dan Politik Hijau.

\begin{abstract}
Contemporary, environmental destruction and its impacts in Indonesia still not adequate to transforms to platform of political party as it appears in other countries. Studies have used a liberal framework and prosecuting collective consciousness and civic participation to control environmental issues, not the urgency of green political representation. Furthermore, perspectives of constitutionalism and institutionalism are too idealistic because inattentive to the individuals interests who are profit oriented. Consequently, this article attempts to analyze the causes of environmental problems and the absence of formal representation of environmental discourse using oligarchy and political representation theory. Using qualitative descriptive studies with interview methods and literature studies discovered: (1) green political discourse in Indonesia was scattered all over the election promises by candidates or political parties, (2) the concentration of natural resources is a sustainable source of income for the oligarchs, (3) the absence of green political platform gave room to live and breathe for oligarch agenda, whereas (4) consolidation of green political platform hampered by internal such as the pros and cons of establishing a political party and external factors such as the party system and Engineering Electoral Systems
\end{abstract}

Keywords: Environmental Destruction, Green Politics, Oligarchy Domination, Political Party and Representation. 


\section{Pendahuluan}

Fungsi partai politik selain sebagai sarana partisipasi politik warga negara juga merupakan sarana penyerap, penghimpun, dan penyalur aspirasi politik masyarakat (Pasal 11 Undang-Undang Nomor 2 Tahun 2008). Salah satu yang tidak pernah absen setiap tahunnya adalah aspirasi terkait kerusakan lingkungan dan dampak kerusakan lingkungan. Pemerintah juga sering kali berjanji untuk mengurangi dampak kerusakan lingkungan, tetapi faktanya, 684.000 hektar hutan hilang akibat pembalakan liar, kebakaran hutan, perambahan hutan, dan alih fungsi hutan setiap tahunnya. Berdasarkan data dari Global Forest Resources Assessment Indonesia menempati peringkat kedua dunia tertinggi kehilangan hutan (Kompas, 2016). Selain itu, pada tahun 2018 WHO mencatat DKI Jakarta dan Bandung masuk dalam 10 besar kota dengan pencemaran terburuk di Asia Tenggara (Dwi, 2018). Di samping itu data terkait dampak kerusakan lingkungan juga tidak kecil, menurut Korlantas Mabes Polri pada tahun 2017 terdapat lebih dari 165.000 orang yang mati akibat polusi udara (Kasmiruddin, 2018). Konsorsium Pembaruan Agraria (KPA) juga mencatat setidaknya 364 orang korban dari konflik agraria di Indonesia selama tahun 2018. 94 di antaranya terkait infrastruktur, 78 konflik pertanian dan 30 konflik kehutanan bahkan 21 kasus kriminalisasi dilakukan oleh polisi (Bayu, 2019).

Selama ini baik kerusakan lingkungan, konflik agraria ataupun penggusuran diselesaikan dengan ganti rugi. Selain tidak menyelesaikan masalah kerusakan lingkungan dan dampaknya, ganti rugi juga sering kali tidak dilakukan. Berdasarkan data Greenpeace Indonesia, Presiden Joko Widodo telah memenangkan gugatan perdata atas 11 perusahaan dan harus membayar ganti rugi akibat kerusakan lingkungan dan kebakaran total lebih $\mathrm{Rp}$ 18 triliun. Presiden Jokowi sendiri menyatakan proses tersebut sedang berjalan, namun menurut Greenpeace ganti rugi belum dilakukan oleh perusahaan terkait (Greenpeace Indonesia, 2019). Senada dengan Greenpeace, Wahana Lingkungan Hidup (Walhi) juga memiliki pandangan serupa, menurut Nur Hidayati (Direktur Walhi) meskipun kasus kebakaran hutan dan lahan (karhutla) di pengadilan sudah inkrah namun uang ganti rugi dan biaya pemulihan lingkungan sulit ditagih. Hal itu menurutnya terkait dengan politik ekonomi atau oligarki yang pada akhirnya mempersulit proses penegakkan hukum (Jingga \& Lestari, 2019).

Berdasarkan gambaran di atas, maka terlihat persoalan lingkungan tidak dapat dilepaskan dari dominasi oligarki. Para teoritis oligarki seperti Jeffrey Winters (2011), Vedi R Hadiz, dan Robison (2013) menggambarkan kekuasaan oligarki meliputi negara dan lembaga-lembaga pemerintahan. Meskipun demikian, sejak transisi tahun 1998 dari otoritarian menuju demokrasi elektoral, menurut Winters (2011), belum terdapat ancaman atas dominasi oligarki dari bawah. Dengan kata lain organisasi masyarakat maupun aktivis lingkungan tidak cukup kuat untuk mengancam dominasi oligarki dalam pengelolaan dan penguasaan sumber daya alam. Selain Greenpeace dan Walhi, aspirasi terkait kerusakan lingkungan dan dampaknya juga diperjuangkan oleh sejumlah kelompok masyarakat dan aktivis lingkungan seperti, World Wide Fund for Nature (WWF) Indonesia, Lindungi Hutan, Friends of The Earth (FOEI), Yayasan Keanekaragaman Hayati Indonesia (KEHATI), Kiara, dan yang lainnya.

Berbeda dengan di Indonesia, persoalan lingkungan di sejumlah negara seperti Inggris, Perancis dan Jerman tidak hanya diperjuangkan oleh kelompok masyarakat dan aktivis lingkungan tetapi justru oleh partai politik hijau (Green Party). Misalnya Die Grünen di Jerman, Green Party of England and Wales (GPEW), Taiwan Ludang, Midori no Tō di Jepang dan Latvijas Zaḷā partija (LZP) di Latvia. Kemunculan partai hijau (green parties) di dunia sering kali dianggap sebagai hal yang baru, tidak lebih tua dibanding partai liberal, konservatif maupun sosialis. Namun meski demikian kesadaran manusia 


\section{Nakhoda: Jurnal Ilmu Pemerintahan \\ Vol. 19 No. 2 Tahun 2020 Halaman 151-167 \\ e-ISSN: 2656-5277 | p-ISSN: 1829-5827}

terhadap alam sejatinya bukan merupakan diskursus yang baru, bahkan semenjak revolusi industri digalakkan telah muncul beragam kritik.

Perkembangan diskursus lingkungan mencapai puncaknya pada pertengahan abad 20 , tepatnya antara dekade 60 -an dan 70 -an ditandai dengan beragam protes para aktivis lingkungan. Gelombang protes tersebut menjadi latar belakang terealisasinya konferensi Lingkungan Hidup PBB untuk pertama kalinya pada tahun 1972 di Stockholm dan disusul dengan KTT Rio de Janeiro pada tahun 1992. Sejak saat itu gerakan lingkungan di banyak negara mulai melibatkan diri secara langsung dalam politik kebijakan pemerintah, salah satunya melalui protes dan kegiatan lobi konvensional (Dalton et al., 2003).

Setelah itu banyak organisasi lingkungan muncul di berbagai negara, beberapa di antaranya berafiliasi dengan Global Greens yang didirikan pada tahun 2001 dan telah memiliki anggota lebih dari 100 organisasi sampai saat ini. 83 di antaranya menjadi partai politik dan mengikuti pemilihan umum sedangkan yang lainnya berafiliasi dalam bentuk organisasi profesional dan amatir (Gahrton, 2015). Global Greens juga membentuk empat federasi, di antaranya The African Green Federation (AGF), The Asia-Pacific Greens Federation (APGF), The European Green Party (EGP) dan The Federation of Green Parties of the Americas (FPVA). Adapun anggota AGPF terdiri dari 11 partai politik dan 8 anggota asosiasi atau profesional, 3 dari 8 anggota asosiasi tersebut berada di Indonesia yaitu Partai Hijau Indonesia (PHI), Sarekat Hijau Indonesia (SHI) dan Atjeh Greens. Tidak seperti di negara lainnya, tiga partai hijau di Indonesia tidak pernah mengikuti pemilihan umum bahkan keberadaannya banyak tidak diketahui oleh masyarakat Indonesia.

Berdasarkan permasalahan di atas, kerusakan dan dampak kerusakan lingkungan di Indonesia seharusnya lebih dari cukup sebagai modal transformasi gerakan lingkungan menjadi platform sebuah partai politik. Sebagaimana isu penutupan reaktor nuklir dan pembangunan proyek stasiun kereta Stuttgart 21 berhasil dimobilisasi Die Grünen atau isu perubahan iklim oleh GPEW di Inggris. Faktanya gerakan lingkungan di Indonesia masih diperjuangkan melalui organisasi masyarakat dan tidak cukup mampu bertransformasi menjadi identitas atau platform partai politik peserta pemilu. Selain itu, ketidakhadiran narasi lingkungan atau politik hijau dalam bentuk platform partai politik peserta pemilu di Indonesia sejauh ini sedikit sekali mendapat perhatian. Artikel ini berupaya menjawab pertanyaan "mengapa narasi politik hijau gagal bertransformasi menjadi partai politik di Indonesia?"

Dalam dasawarsa terakhir, para teoritis oligarki kurang banyak menaruh perhatian terhadap sumber daya alam sebagai pendapatan oligarki dan dampaknya terhadap kerusakan lingkungan. Kausalitas dominasi oligarki terhadap pengelolaan sumber daya alam tidak dapat dijelaskan hanya dengan tipologi oligarki dari Winters (panglima, sultanistik, oligarki dan sipil). Dalam upaya menjawab pertanyaan di atas, studi ini menggunakan kerangka teori oligarki untuk menjelaskan aktor utama dibalik kerusakan lingkungan dan teori keterwakilan untuk menjelaskan dampak dominasi oligarki terhadap ketidakhadiran narasi politik hijau dalam bentuk platform partai politik.

\section{Metode}

Metode yang digunakan dalam penelitian ini adalah kualitatif deskriptif. Terdapat dua teknik pengumpulan data, yakni data primer melalui wawancara mendalam (in-depth interviews), sedangkan untuk data sekunder dilakukan studi literatur yang dapat membantu menguatkan argumen dalam artikel ini, seperti: hasil riset sebelumnya yang terkait dengan topik, Twitter, video YouTube dan pemberitaan media massa online. Selain itu, digunakan batasan penelitian berdasarkan lokasi, informan, peristiwa dan proses. Lokasi difokuskan pada modal alam (natural capital), yakni konsentrasi penguasaan dalam kawasan hutan lindung, daerah aliran sungai, danau, pesisir dan lain-lain yang pada dasarnya tidak dapat 


\section{Nakhoda: Jurnal Ilmu Pemerintahan \\ Vol. 19 No. 2 Tahun 2020 Halaman 151-167 \\ e-ISSN: 2656-5277 | p-ISSN: 1829-5827}

dimiliki perseorangan. Informan pada penelitian adalah Chairil Syah selaku salah satu aktor yang mendirikan Partai Hijau Indonesia (PHI), Tubagus Soleh Ahmadi (Koordinator Walhi Jakarta), Abdul Halim (Pengamat Perikanan dan Direktur Pusat Kajian Maritim untuk Kemanusiaan), dan Bambang Susanto (Pengamat Infrastruktur dan Tenaga Ahli Kementerian Koordinator Kemaritiman Maritim 2015-2016). Batasan peristiwa dan proses penelitian diambil berdasarkan metode longitudinal "deret waktu" yang memungkinkan penelitian dapat mengamati stabilitas atau perubahan dalam karakteristik unit dan dapat melacak kondisi sepanjang waktu. Adapun batasan peristiwa dan proses tersebut dilihat sejak reformasi 1998.

\section{Hasil dan Pembahasan}

Keterlibatan gerakan lingkungan dalam politik diimplementasikan dalam berbagai bentuk, seperti partai politik, lembaga masyarakat atau gerakan masyarakat itu sendiri (volunteer). Bentuk gerakan politik lingkungan atau yang kemudian disebut sebagai politik hijau di Indonesia sampai saat ini diimplementasikan dengan pengajuan petisi, gugatan atas kebijakan dan aksi mobilisasi massa. Sebagai contoh pada kebakaran hutan dan lahan (karhutla) yang terjadi di Provinsi Riau tahun 2014, Walhi dan Greenpeace mengajukan petisi online melalui platform change.org dan surat resmi kepada Presiden Joko Widodo untuk melakukan "blusukan asap". Kemudian pada kasus Limbah di Sumedang Jawa Barat, Walhi dan Greenpeace melakukan gugatan terhadap Bupati Sumedang yang telah menerbitkan Izin Pembuangan Limbah Cair (IPLC) untuk Kahatex, PT. Insan Sandang, dan PT. Five Star di Pengadilan Tata Usaha Negeri (PTUN) Bandung pada tahun 2016. Sementara itu, contoh gerakan aksi mobilisasi massa yang dilakukan kelompok masyarakat dan aktivis lingkungan sudah sangat sering terjadi mulai dari isu perubahan iklim, kebakaran hutan, reklamasi sampai terlibat dalam bagian aksi \#reformasidikorupsi pada bulan September 2019 bersama dengan kelompok mahasiswa dan buruh.

Terkait persoalan kerusakan lingkungan, menurut Abdul Halim, "sulit rasanya percaya pada proses hukum yang terjadi jika selama ini perusahaan sering kali memenangkan pengadilan" (Wawancara Pribadi, 2020). Bahkan menurutnya, sekalipun kelompok masyarakat atau aktivis lingkungan memenangkan gugatan biasanya tidak bertahan lama sebelum akhirnya digugat kembali. Contohnya pada kasus gugatan nelayan atas Surat Keputusan (SK) Gubernur DKI Nomor 2.238 Tahun 2014 tentang Pemberian Izin Reklamasi Pulau G di Teluk Jakarta kepada PT. Muara Wisesa Samudra, PTUN Jakarta mengabulkan gugatan tersebut sebelum akhirnya banding yang dilakukan Gubernur DKI Jakarta Basuki Tjahaja Purnama ke Mahkamah Agung (MA) diterima pada 17 Oktober 2016 atau lima bulan setelah penetapan PTUN Jakarta.

Berbeda dengan di Indonesia, gerakan politik hijau di sejumlah negara berhasil bertransformasi menjadi partai politik hijau (Gahrton, 2015). Per Januari 2015 ada hampir 100 partai politik (mewakili sekitar 90 negara) yang berafiliasi dengan struktur Global Greens. Di sisi lain perkembangan partai politik hijau (green parties) di dunia mengalami banyak dinamika, beberapa di antara mereka berhasil menempatkan perwakilan di parlemen sebagaimana yang terjadi di Jerman, United Kingdom (UK), Brazil dan Swedia. Namun, di Peru, Mesir, Albania, dan Azerbaijan partai lingkungan tidak memiliki perwakilan di parlemen.

Partai Hijau Jerman menjadi contoh gerakan politik hijau di banyak negara, pasalnya koalisi Die Grünen bersama dengan Sozialdemokratische Partei Deutschlands (SPD) berhasil memenangi pemilu Landtag di negara bagian Baden-Wurttemberg tahun 2011 dan menempatkan Winfried Kretschmann sebagai Perdana Menteri saat itu, mengalahkan Christlich Demokratische Union Deutschlands (CDU) yang berkuasa sejak tahun 1953. Popularitas Partai Hijau juga terus meningkat sampai tahun 2019, pemilihan 


\section{Nakhoda: Jurnal Ilmu Pemerintahan \\ Vol. 19 No. 2 Tahun 2020 Halaman 151-167 \\ e-ISSN: 2656-5277 | p-ISSN: 1829-5827}

umum Eropa menunjukkan blok partai-partai Hijau yang cenderung beraliran kiri, menduduki peringkat keempat dalam pemilu dengan perolehan 69 kursi daro total 751 kursi. Angka itu meningkat jauh dari 17 kursi yang didapatkan dalam pemilu 2014 (VOA Indonesia, 2019). Menurut Botetzagias \& Van Schuur (Botetzagias \& Van Schuur, 2012) ada tiga faktor dalam keberhasilan dari gerakan politik hijau di antaranya: (1) efektivitas dalam membangun persepsi; (2) kepercayaan, nilai dan ideologi, dan; (3) identitas dan dorongan jaringan.

Gerakan politik hijau di Indonesia terimplementasi dalam bentuk yang berbeda dengan Negara seperti Jerman, Inggris, dan Australia, di mana gerakan lingkungan mengidentitaskan dirinya dalam partai politik. di Indonesia isu lingkungan sering kali dijadikan komoditas politik menjelang kontestasi pemilu, sebagaimana ditegaskan oleh Abdul Halim "janji kampanye yang dulu itu (isu lingkungan) tidak lebih dari komoditas politik yang digunakan untuk mencari suara rakyat saja" (Wawancara Pribadi, 2020). Senada dengan itu, sejumlah literatur menunjukkan isu lingkungan tersebar di berbagai partai politik ketika menjelang pemilihan umum (Kusno, 2011; Qodriyatun, 2008) atau sebagai janji kampanye kandidat tertentu (Lay, 2007; Yenrizal \& Izomiddin, 2017). Misalnya, penelitian Abidin Kusno (2011) mengenai narasi "Green House" oleh Partai Kebangkitan Bangsa (PKB) di Jakarta pada tahun 2007 bertujuan sebatas citra kampanye elite politik. Pasalnya turunan konsep tersebut tidak mengatur populasi perkotaan ataupun merespons bahaya pemanasan global melainkan hanya menawarkan peranan teknologi dalam formula politik hijau di perkotaan. Selain itu, penelitian Yenrizal dan Izomiddin (2017) terkait Pilkada 2018 di Palembang melihat strategi kampanye incumbent, yaitu $\mathrm{H}$. Harnojoyo yang menggunakan isu lingkungan. Meskipun ia maju lewat Partai Demokrat namun citra yang dibangun justru adalah individu yang peduli akan lingkungan.

Sebenarnya pada 5 Juni 2012 sempat dideklarasikan Partai Hijau Indonesia (PHI) oleh sejumlah petani, buruh, dan aktivis lingkungan yang diinisiasi oleh Chairil Syah, dkk. di Bandung. Chairil Syah sendiri merupakan mantan Koordinator Nasional Walhi dan Dewan Penasihat YLBHI (Yayasan Lembaga Bantuan Hukum Indonesia), sehingga terlibat juga dalam deklarasi tersebut jaringan Serikat Pekerja Progresif, Ikatan Walhi Internasional, dan Serikat Hijau Indonesia (SHI). Deklarasi PHI diharapkan dapat memperjelas signifikansi isu lingkungan dalam konstelasi politik Indonesia, tetapi faktanya justru PHI tidak cukup mampu bahkan belum sampai mengikuti kontestasi pemilu 2014 partai tersebut sudah bubar.

Gerakan politik hijau yang diperjuangkan kelompok masyarakat dan aktivis lingkungan di Indonesia pada dasarnya bersumber pada kerangka berpikir mazhab realis yang memandang perlunya keamanan sebagai solusi atas persoalan kerusakan lingkungan (Hardin, 1968). Sebagai contoh. Chairil Syah memandang kerusakan lingkungan yang terjadi merupakan akibat dari penyalahgunaan kekuasaan dan kebijakan yang merugikan masyarakat, "selama ini kita masyarakat kecil dan lingkungan tidak jadi pertimbangan para politisi dalam membuat kebijakan. Untuk melindungi itu semua tidak ada pilihan lain, kita mesti bersatu dan ikut dalam kontestasi kekuasaan" (wawancara pribadi, 2020). Di sisi lain literatur ilmuwan Indonesia sering kali mendasarkan pandangannya pada kerangka berpikir mazhab liberalis atau Malthusian yang menuntut adanya kesadaran kolektif (Arifin, 2012; Pratiwi, 2007; Yusri \& Adlin, 2017) atau kerja sama antara lembaga pemerintah (Azhar, 2007; Khotami, 2020; Siombo, 2014; Tolo, 2014). Misalnya, studi Ali Yusri dan Adrin (2017) yang memandang penyelesaian kasus kabut asap di Pekanbaru tahun 2014 dikarenakan adanya kesadaran kolektif organisasi masyarakat dan pemerintah. Meskipun mampu memaksa pemerintah untuk turut serta namun proses hukum terhadap pelaku sampai saat ini masih belum selesai, setidak-tidaknya berdasarkan data Greenpeace perusahaan masih belum membayar ganti rugi (Greenpeace Indonesia, 2019). Sebaliknya, 


\section{Nakhoda: Jurnal Ilmu Pemerintahan \\ Vol. 19 No. 2 Tahun 2020 Halaman 151-167 \\ e-ISSN: 2656-5277 | p-ISSN: 1829-5827}

dalam kasus yang lain menurut studi Khotami (2020) justru menuntut adanya kerja sama kelembagaan antara pemerintah provinsi dan pemerintah kabupaten, DPRD dan masyarakat dalam mengatasi masalah penambangan emas tanpa izin di Kabupaten Kuantan Singingi. Bahkan yang lebih idealis, studi Anna Yulia Hartati (2007) mendorong kerja sama internasional antara negara maju dan negara berkembang. Studi lainnya terkait narasi lingkungan dalam perspektif politik juga dikaji melalui aspek internasional (Arifin, 2012) maupun nasional (Mutia \& Asteria, 2018; Shohibuddin, 2016) dan di antaranya fokus pada peranan negara dalam hal ini pemerintah (Dethier, 2017; Kusno, 2011; Swainson \& Mahanty, 2018) dan lembaga masyarakat (García et al., 2007; Nomura, 2007; Nooteboom \& De Jong, 2010). Perbedaan pandangan terkait relasi manusia dan alam dirumuskan pada Tabel 1.

Tabel 1. Mazhab Politik Hijau

\begin{tabular}{llll}
\hline \multicolumn{1}{c}{ Ciri-ciri } & \multicolumn{1}{c}{ Liberalis } & \multicolumn{1}{c}{ Realis } & \multicolumn{1}{c}{ Radikal } \\
\hline Posisi Alam & Objek & Objek & Subjek \\
Sumber konflik & Kelangkaan & Kelangkaan & Dominasi \\
Unit Analisa & Agen Supranasional & Agen Individu & Kebijakan \\
Fokus & Kesadaran Kolektif & Persaingan & Hierarki \\
Solusi & Kerja sama/negosiasi & Keamanan & Perubahan sistem \\
& & lingkungan & sosial \\
Literatur & Malthus (1798), Bryner & Hardin (1968), & Arne Naess (1973), \\
& (2001), Wapner (1995), Luciani (2015), & Merchant (1993), \\
& dll. & Ophuls (1977), dll. & dll. \\
\hline
\end{tabular}

Sumber: Berbagai Sumber. Data Diolah. 2020.

Cara bagaimana lingkungan atau alam didefinisikan oleh para ilmuwan merupakan faktor penting yang membedakan satu dengan yang lainnya. Ilmuwan liberalis dan realis sama-sama memandang bahwa posisi alam merupakan objek bagi manusia sedangkan ilmuwan yang lain memandang alam sebagai subjek seperti halnya manusia (Naess, 1973; Pulido \& Merchant, 1993). Pandangan radikal atau deep ecology tidak banyak digunakan di Indonesia baik oleh para ilmuwan maupun aktivis lingkungan. Adapun kelompok lingkungan dan aktivis pada dasarnya tidak menuntut perubahan sistem sosial secara radikal sebagaimana kaum deep ecology. Kritik yang sering kali diajukan ialah pembenahan sistem dan perbaikan keamanan lingkungan misalnya rapor merah yang diajukan oleh Walhi terhadap Gubernur DKI Jakarta Anies Baswedan. Menurut Tubagus Saleh Ahmadi, Ketua Walhi Jakarta, meskipun ada sekitar 17 kebijakan mengenai lingkungan yang diterbitkan Anies Baswedan selama menjabat sejak 2017, namun pelaksanaannya buruk. Menurut Tubagus "setiap gubernur sama saja, kebijakan (lingkungan) hanya dijadikan alat politik, tidak benar-benar serius" (Wawancara Pribadi, 2020). Selain itu, Tubagus juga menilai pertimbangan kebijakan pemerintah tidak cukup komprehensif dan hanya didasarkan pada asumsi.

Faktor yang menjadi latar belakang kerusakan lingkungan dan dampaknya bukan hanya soal penyalahgunaan wewenang dan ketidakefektifan penegakkan hukum tetapi, menurut Ophuls (1977) dalam Bowman (Bowman, 1978), juga disebabkan faktor ketidakmerataan dan faktor tekanan kekuasaan. Pemerintahan Soeharto telah mewariskan ketimpangan struktur agraria dan hasilnya, menurut data World Bank tahun 2015, terdapat $1 \%$ keluarga di Indonesia yang menguasai 50\% lebih kekayaan bangsa Indonesia. Senada dengan itu, menurut Tubagus, "model pembangunan dengan cara ekstraksi sumber daya alam jelas-jelas gagal karena hanya merusak alam dan menghilangkan sumber-sumber kehidupan rakyat. Contoh yang paling nyata adalah Undang-Undang Minerba" 


\section{Nakhoda: Jurnal Ilmu Pemerintahan \\ Vol. 19 No. 2 Tahun 2020 Halaman 151-167 \\ e-ISSN: 2656-5277 | p-ISSN: 1829-5827}

(Wawancara, 2020). Selain Undang-Undang Minerba, Tubagus juga menilai logika Presiden Jokowi mengundang investasi melalui Undang-Undang Cipta Kerja juga omong kosong, hal itu justru menunjukkan wajah pemerintah sebagai bagian dari oligarki yang pada akhirnya memperparah kesenjangan ekonomi antara "si kaya" dan "si miskin".

Dalam dasawarsa terakhir, ketimpangan material dan pengelolaan sumber daya alam menjadi topik yang populer di kalangan ilmuwan Indonesia. Komisi Pemberantasan Korupsi (KPK) dalam Nota Sintesis tahun 2018 melaporkan adanya ketimpangan pemanfaatan SDA, di antaranya: usaha kehutanan, dengan perbandingan 96:4 antara perusahaan besar (40.463.103 Hektar) dan masyarakat (1.748.931 Hektar); usaha perkebunan sawit, 2.535.495 Hektar dikuasai oleh 10 perusahaan besar, sedangkan 2,1 juta pekebun rakyat hanya menguasai 4.756.272 Hektar; tambang minerba, Izin Pertambangan Rakyat yang diterbitkan sebanyak 171 dengan luas 3,2 Hektar/izin dan penerbitan IUP sebanyak 5.589 usaha dengan luas rata-rata 3.245 Hektar/IUP, sedangkan Kontrak Karya yang diterbitkan sebanyak 32 usaha memiliki rata-rata 40.753 Hektar/KK dan PKP2B sebanyak 26 usaha dengan luas rata-rata 28.575 Hektar/usaha. Usaha dengan skala besar, menurut KPK, menyebabkan tekanan konversi lahan-lahan produksi bagi masyarakat desa, di antaranya 535 Hektar/hari lahan pertanian hilang (KPK RI, 2019).

Hasil evaluasi KPK Gerakan Nasional Penyelamatan Sumber Daya Alam (GNPSDA) menunjukkan perspektif yang berbeda dari studi-studi sebelumnya yang memandang kerusakan lingkungan dan dampaknya dari perspektif konstitusional, institusional dan paradigmatis. Menurut KPK, ketimpangan pemanfaatan SDA dikarenakan peranan "institusi alternatif" (pseudo legal), yakni: "segelintir kelompok yang memiliki gurita penguasaan sistem dan struktur kuasa (sosial, ekonomi dan politik) yang kuat mampu meraup ragam keuntungan dengan cara-cara sistemik”. (KPK RI, 2019:3). Institusi tersebut merupakan jaringan yang dipelihara oleh kekuasaan, yang secara de facto lebih besar dari kekuasaan legal negara. Winters (2011) menggambarkan bahwa orang-orang kaya akan berupaya untuk tidak hanya memperkaya dirinya sendiri tetapi juga menjaga apa yang dimilikinya, salah satunya dengan ikut serta dalam proses politik. Winters (2011) juga mendefinisikan kelompok minoritas kaya yang berkuasa atau pseudo legal (sebagaimana yang dimaksud KPK) ini sebagai oligarki, menurutnya oligarki adalah "politik pertahanan kekayaan oleh pelaku yang memiliki kekayaan material" (2011, p. 10), sedangkan yang dimaksud oligarki adalah "pelaku yang menguasai/memimpin dan mengendalikan konsentrasi besar sumber daya material yang bisa digunakan untuk mempertahankan atau meningkatkan kekayaan pribadi dan posisi sosial eksklusifnya" (2011, p. 8). Lingkungan atau sumber daya alam merupakan sumber pendapatan oligarki dan oleh karenanya akan senantiasa dipertahankan.

Dominasi oligarki pasca reformasi berbeda dengan sebelumnya pada masa Orde Baru, di mana para oligarki di era Orde Baru cukup memiliki kedekatan dengan keluarga Suharto ataupun para petinggi militer (Sugiarto, 2018). Pasca jatuhnya Soeharto tahun 1998 tidak serta merta menghilangkan para pemilik modal, menurut Winters oligarki itu tetap ada namun berubah dari "Oligarki Panglima" atau oligarki yang muncul dengan kekuasaan pemaksa (kekerasan) secara langsung pada dirinya menjadi "Oligarki Kolektif” yakni oligarki yang berkuasa melalui lembaga yang memiliki norma atau aturan main. Kekuasaan oligarki bersumber dari kekayaan atau harta (property) dan pendapatan (income).

Dominasi oligarki tidak hanya meliputi akumulasi kekayaan dan pendapatan tetapi juga pertahanan kekayaan dan pendapatan. Winters (2011) secara spesifik menggunakan istilah dominasi material untuk membedakan oligarki dengan elite. Namun menurut Bambang Susanto, di Indonesia tidak mengenal istilah oligarki atau cukong karena faktanya pengusaha-pengusaha di Indonesia tidak pernah membentuk kekuatan secara mandiri melainkan justru menggandol pada elite politik (wawancara pribadi, 2020). Menurutnya 


\section{Nakhoda: Jurnal IImu Pemerintahan \\ Vol. 19 No. 2 Tahun 2020 Halaman 151-167 \\ e-ISSN: 2656-5277 | p-ISSN: 1829-5827}

juga, meskipun orde baru sudah runtuh namun oligarki tetap tidak dapat seenaknya karena elite politik tetap memiliki pengaruh yang kuat melalui kebijakannya. Akhirnya oligarki harus menjalin kerja sama dengan elite politik, karena di sisi lain elite politik juga mendapatkan keuntungan dengan pengembangan wilayah politik.

Senada dengan itu, menurut Hadiz \& Robison (Hadiz \& Robison, 2013; 2004) para oligarki yang dulu dominan sekarang dipaksa untuk beroperasi dalam suatu arena di mana tarik-menarik politik dimediasi melalui partai-partai dan parlemen. Sebagai contoh hampir di setiap partai diisi oleh pemilik modal yang terkait dengan industri ekstraktif, baik itu ketua umum ataupun founder partai politik, seperti: Surya Paloh (Nasdem) memiliki 60\% saham tambang emas Beutong di Aceh, Perusahaan Nusantara Group milik Prabowo (Gerindra), dan PT. Lapindo Brantas milik Aburizal Bakrie (Golkar). Selain itu, beberapa tokoh partai lain juga sempat muncul namanya dalam beberapa kasus seperti: Zulkifli Hasan (PAN) terkait adanya operasi PT. Baramega Citra Mulia Persada (Batubara) di wilayah Kalimantan Selatan, dan Susilo Bambang Yudhoyono (Demokrat) dalam kasus pengadaan minyak selama periode 2012-2014 pada anak usaha PT. Pertamina, Pertamina Energy Trading Ltd. (Petral). Selain itu temuan Transparency International Indonesia (2013) juga menunjukkan bahwa semua partai politik tidak mau mengungkapkan keuangan mereka. Selain berhubungan dengan kepala daerah dan partai politik, oligarki pasca reformasi juga mendirikan partai-partai baru misalnya Prabowo dan Surya Paloh.

Sumber daya alam sebagai pendapatan oligarki tidak hanya terkonsentrasi dan dimonopoli oligarki tetapi juga menyebabkan ketimpangan dan kerugian negara. Pasca reformasi, tercatat pada tahun 2017 pengelolaan sumber daya alam (SDA) menyumbang sebesar 1.480,04 Triliun atau 10,89\% dari total keuntungan PDB Indonesia. Namun alihalih menjadi aset pembangunan dan pertumbuhan ekonomi, pengelolaan SDA juga sering kali menyumbang pada kerugian negara. Menurut Koordinator Divisi Hukum dan Monitoring Peradilan Indonesia Corruption Watch (ICW), Tama S Langkun, dalam kurun waktu 2010-2017 sekurang-kurangnya terdapat 115 kasus korupsi dan 326 orang menjadi tersangka dalam perkara korupsi sumber daya alam, di antaranya dari sektor perkebunan, kehutanan dan pertambangan. Enam kasus saja, menurut Tama, memiliki potensi kerugian negara sebesar 7,26 Triliun (CNN Indonesia, 2018). Selain itu, Komisi Pemberantasan Korupsi (KPK) juga menetapkan Bupati Kota Waringin Timur Supian Hadi (5,8 Triliun), Mantan Gubernur Sulawesi Tenggara Nur Alam (2,78 T) dan Mantan Bupati Konawe Utara Aswa Sulaiman (2,7 Triliun) sebagai tersangka. Kasus korupsi pejabat daerah selain karena penyalahgunaan kekuasaan juga bisa terjadi karena hubungan antara bisnis dan negara atau dengan kata lain konspirasi antara pejabat publik dan perusahaan swasta (Syarif \& Faisal, 2019).

Kaitan antara oligarki sebagai pendonor dan kandidat juga digambarkan dalam studi Aspinall \& Berenschot (Aspinall \& Barenschot,2019) bahwa pasca pemilihan umum para penyandang dana menagih janji agar mendapatkan kontrak, kredit, proyek dan keuntungankeuntungan lainnya. politisi kadang-kadang membayar para pendana kampanye mereka dengan mengadopsi kebijakan publik yang menguntungkan mereka, dan yang lebih sering adalah para politisi membantu para pebisnis yang mendukung mereka dengan memanipulasi dan menyiasati peraturan yang ada atas nama mereka (Aspinall \& Barenschot, 2019, p. 299). Keikutsertaan oligarki dalam politik membuat segelintir orang tersebut mendapatkan kemudahan dalam mengakses sumber daya alam milik negara. Bentuk kemudahan itu bisa berupa izin maupun regulasi. Dalam hal izin misalnya berdasarkan identifikasi Kementerian Keuangan per November 2012, dikutip dari tulisan Bambang Widjojanto (2017), menyatakan bahwa "Tanah-tanah yang saat ini dilewati oleh LRT, MRT, dan Kereta Api sudah banyak dikuasai swasta”. Padahal menurut Widjojanto hal itu tidak tertera dalam Rencana Pembangunan Jangka Menengah Nasional (RPJMN) 


\section{Nakhoda: Jurnal Ilmu Pemerintahan \\ Vol. 19 No. 2 Tahun 2020 Halaman 151-167 \\ e-ISSN: 2656-5277 | p-ISSN: 1829-5827}

2015-2019. Menurut Widjojanto, pemberian izin di sektor SDA senantiasa berkaitan dengan high cost politic dalam pemilihan kepala daerah.

Spesifik terkait sumber daya alam dan kepentingan bisnis sudah terjadi pada era Orde Baru dan masih terjadi sampai dengan tradisi yang sama yaitu menurut Bambang Susanto, partai birokrat yang memiliki bisnis sekaligus memiliki kewenangan tetapi memiliki sejumlah hambatan sehingga akhirnya menyalurkan kewenangan itu kepada perusahaan. Bahkan menurutnya tidak ada bisnis yang murni di Indonesia, semuanya terkait dengan politik (Wawancara Pribadi, 2020).

Selain itu contoh kerja sama oligarki dan pejabat juga ditunjukkan melalui investigasi media detik.com (2016) pada kasus yang Reklamasi Pantai Utara. Hasil investigasi tersebut memperlihatkan adanya keikutsertaan pengembang dalam kampanye Joko Widodo, Gubernur DKI Jakarta yang saat itu telah resmi menjadi calon presiden pada pemilu 2014. BTP yang saat itu masih menjabat Wakil Gubernur DKI Jakarta menghadiri penandatanganan kewajiban tambahan kontribusi bagi pengusaha pengembang reklamasi Teluk Jakarta yang digelar di ruang rapat Balai Kota DKI Jakarta. Dalam rapat tersebut BTP mengatakan "kalau ini diberesi, 2017 tidak usah kasih duit kita kampanye, pak" pernyataan tersebut disambung oleh Ariesman Widjaja, Direktur Utama PT. Muara Wisesa Samudra, "Asyik... enggak usah. Ini saja sumbangan saya, ya, pak. Sudah jadi langsung, ya". Selain PT. Muara Wisesa Samudra, pengembang yang hadir dalam rapat tersebut adalah PT. Jaladri Kartika Ekapaksi dan PT. Taman Harapan Indah. Terkait hal ini, Basuki juga dapat dikategorikan berdasarkan tipologi Mietzner (2014) sebagai politisi yang menjalankan bisnis untuk membiayai operasi politik mereka. Selain itu, pada pemilihan umum 2019, bahwa komposisi terbesar (80\%) sumbangan dana kampanye Joko WidodoMa'ruf Amin berasal dari kelompok dan perusahaan yang sebagian merupakan oligarki (Ma'mun \& Kosandi, 2020).

Pada kasus yang sama, yaitu reklamasi Pantura, dominasi oligarki juga mewujud dalam bentuk pengerahan sumber daya materialnya bagi profesional spesialis, seperti: pengacara, akuntan, konsultan penghindaran pajak dan pelobi (Winters, 2011, p. 36). Misalnya, di saat para pengembang atau oligarki mendapat ancaman. Respons para pengembang juga beragam, menanggapi ancaman dari Kementerian Lingkungan Hidup tahun 2003 dan kebijakan pencabutan izin 13 pulau reklamasi, para pengembang menyewa profesional seperti pengacara untuk melakukan gugatan. Sedangkan pada menghadapi ancaman gubernur Basuki Tjahaja Purnama yang meminta tambahan kontribusi $15 \%$, respons pengembang justru melakukan upaya suap terhadap anggota DPRD DKI Jakarta Muhammad Sanusi. Berbeda lagi dengan respons terhadap moratorium reklamasi oleh Menko Rizal Ramli di mana para pengembang menggunakan kedekatannya dengan rezim nasional untuk menghilangkan ancaman dari Rizal Ramli (Winarno, 2016).

Ragam respons pengembang dalam hal ini menegaskan klaim Winters terkait metode pertahanan kekayaan (wealth defense). Terkait oligarki dalam kasus reklamasi, Menurut Tubagus sejak awal bukan program pemerintah tetapi kepentingan bisnis yang difasilitasi pemerintah, "baru ketika reklamasi mendapat protes dari menteri lingkungan hidup Pak Nabil Makarim juga masyarakat sipil, nelayan memprotes saat itu baru kemudian reklamasi ini dibawa-bawa menjadi solusi bagian dari lingkungan hidup" (Wawancara Pribadi, 2020). Senada dengan itu, menurut Abdul Halim mustahil menegasikan keberadaan oligarki karena faktanya selama ini aturan-aturan yang dibuat memang menguntungkan kepentingan bisnis bahkan pergantian elite birokrat tidak banyak mempengaruhi persoalan lingkungan yang ada di Indonesia.

Sepanjang perjalanan sejarah, kekayaan material yang terkonsentrasi pada minoritas selalu mengundang ancaman dari pihak luar yang ingin menguasai atau mendistribusi ulang kekayaan tersebut (Winters, 2011:9). Di samping itu, sebagaimana bentuk kekuasaan 


\section{Nakhoda: Jurnal IImu Pemerintahan \\ Vol. 19 No. 2 Tahun 2020 Halaman 151-167 \\ e-ISSN: 2656-5277 | p-ISSN: 1829-5827}

lainnya dominasi juga mensyaratkan adanya perlawanan. Ancaman terhadap dominasi oligarki tidak hanya berasal dari elite pemerintah tetapi juga dari politisi dan aktivis sebagaimana dicontohkan oleh Aspinall (Aspinall, 2014), dan Mietzner (2014). Khusus terkait narasi politik hijau di Indonesia sejauh ini hanya diperjuangkan oleh aktivis lingkungan seperti Walhi, Greenpeace, dan yang lainnya (Susanti \& Afrizal, 2018). Ketidakhadiran narasi politik hijau dalam bentuk keterwakilan formal memang tidak menjamin rendahnya pertimbangan lingkungan dalam pembuatan keputusan. Namun dalam sistem demokrasi keterwakilan sangat penting, selain untuk menyetarakan identitas juga untuk menghadirkan alternatif pertimbangan. Menurut Hannah Pitkin dalam (Arnesen \& Peters, 2018) representasi politik adalah upaya menghadirkan yang tidak hadir. Pitkin juga membagi representasi ke dalam empat model, yakni representasi formal, deskriptif, substansi dan simbolik. Salah satu kekuatan dari representasi formal dibanding representasi yang lain adalah acting with authority.

Sebenarnya upaya transformasi keterwakilan formal sempat beberapa kali dilakukan (1980, 1998, 2007 dan 2012) oleh Walhi dan sejumlah tokoh lainnya, seperti Dr. Rer. Nat. H. Widyatmoko (Dosen Fakultas Teknik Lingkungan Universitas Trisakti) dan Dr. Ir. Ign. Heruwasto (Dosen Fakultas Ekonomi Universitas Indonesia), namun selalu berujung kegagalan. Terakhir pada 5 Juni 2012 sejumlah petani, buruh, dan aktivis lingkungan yang diinisiasi oleh Chairil Syah, dkk. mendeklarasikan Partai Hijau Indonesia (PHI) di Bandung. Chairil Syah sebelumnya merupakan mantan Koordinator Nasional Walhi dan Dewan Penasihat YLBHI (Yayasan Lembaga Bantuan Hukum Indonesia), sehingga terlibat juga di dalam deklarasi tersebut jaringan Serikat Pekerja Progresif, Ikatan Walhi Internasional, dan Serikat Hijau Indonesia (SHI). Menurut Chairil Syah, pembahasan mengenai pendirian partai hijau sudah terjadi sejak tahun 2004 pada Pertemuan Nasional Lingkungan Hidup. Namun menurutnya "saat itu hasil dari pertemuan 5 region masih mentah dan belum siap untuk mendirikan partai” (Wawancara Pribadi, 2020).

Penundaan itu, menurut Chairil Syah diisi dengan pembelajaran para aktivis melalui magang di berbagai partai. Menurut Chairil Syah "tentu saja kita mempertimbangkannya dalam tim asesmen yang saat itu dibentuk. Meskipun pada akhirnya kami kembali gagal" (Wawancara Pribadi, 2020). Hal yang patut disayangkan adalah para aktivis magang di partai politik yang ada justru malah nyaman sehingga tidak lagi kembali. Akhirnya Walhi membentuk BP3OPK (Badan Persiapan Pembangunan Organisasi Politik Kerakyatan) 6 bulan setelah pertemuan nasional. Hasilnya pada tahun 2007 pada Kongres Pendirian yang bersamaan dengan Konferensi Walhi dibentuklah Sarekat Hijau Indonesia (SHI) yang fokus pada pendampingan.

Menurut Chairil Syah, polarisasi antara orang-orang yang mendukung pendirian partai dan yang hanya menginginkan ormas senantiasa mewarnai setiap pertemuan sampai pada akhirnya tahun 2012, "kami menggelar deklarasi PHI bersama dengan kawan-kawan lain seperti Greenpeace yang saat itu mengamanatkan kepada Berry Nahdiyan Furqon untuk menjadi ketua dan mempersiapkan kongres selanjutnya" (Wawancara Pribadi, 2020). Namun lagi-lagi langkah ini gagal dan satu tahun kemudian Berry mundur dari jabatannya digantikan John Muhammad. Menurut Chairil Syah, kegagalan yang berulang ini dikarenakan "pro-kontra yang terjadi di internal aktivis lingkungan itu sendiri" (Wawancara Pribadi, 2020). Sementara itu, menurut Muhammad dan Abraham (2016) dalam tulisannya melihat kesadaran masyarakat akan kerusakan lingkungan dan kebutuhannya untuk memperbaiki lingkungan tetapi terdapat paradoks di masyarakat, yaitu "Kita anti parpol, tapi kita sadar membutuhkan parpol untuk menentukan kemenangan agenda publik". Hal itulah yang menjadi salah satu kesulitan Partai Hijau berkembang di Indonesia.

Faktor lainnya juga penulis dapatkan dari wawancara bersama Chairil Syah, 


\section{Nakhoda: Jurnal Ilmu Pemerintahan \\ Vol. 19 No. 2 Tahun 2020 Halaman 151-167 \\ e-ISSN: 2656-5277 | p-ISSN: 1829-5827}

meskipun tidak secara eksplisit namun proses pendirian partai juga terhambat karena selama ini keuangan hanya didasarkan dari Walhi. Dengan kata lain, isu lingkungan nyatanya tidak menarik banyak investor untuk mensponsori pendirian partai apalagi oligarki. Tentu saja Chairil Syah juga sependapat ketika penulis tanyakan terkait kemungkinan pemodal ketika partai tersebut ikut kontestasi, menurutnya "saya belum terpikirkan tapi pasti hal itu akan sulit melihat para pemodal di Indonesia justru adalah oligarki. Kita mesti memiliki penawaran untuk mereka dan sepertinya itu adalah PR besar" (Wawancara Pribadi, 2020).

Ketidaksesuaian isu yang diperjuangkan oleh PHI dengan para pemodallah yang juga akan menyulitkan, bagaimanapun Chairil Syah menyadari bahwa "sulit sekali berkontestasi dengan partai- partai yang ada, yang justru memiliki para pemodal besar, kita mesti menyusun rencana lain yakni menanamkan militansi pada masyarakat" (Wawancara Pribadi, 2020). Pada 23 Maret 2019 lalu, Walhi menggelar "Rapat Akbar dan Konsolidasi Politik Gerakan Lingkungan Hidup" di Gelora Bung Karno. Salah satu hasilnya adalah mengusung Platform Politik hijau Hidup Indonesia yang fokus padan 6 agenda politik, di antaranya secara garis besar: (1) memastikan pengembalian kembali kewajiban negara sebagai benteng Hak. Asasi Manusia; (2) penataan ulang relasi negara, di mana rakyat harus ditempatkan sebagai aktor utama; (3) pengakuan dan perlindungan Wilayah Kelola Rakyat; (4) penyelesaian konflik sumber daya alam dan lingkungan hidup; (5) pemulihan lingkungan hidup, dan; (6) mendorong negara menjamin pengakuan dan perlindungan kepada perempuan dalam pengelolaan lingkungan hidup dan sumber daya alam. Saat itu, Walhi masih menilai adanya kesulitan dalam menghadirkan narasi politik hijau dalam bentuk platform partai politik.

Meski demikian, menurut Nur Hidayati, Direktur Eksekutif Walhi Nasional dalam sesi diskusi pada Perayaan Ulang Tahun Walhi ke-39 menyatakan bahwa adanya kondisi yang mendesak saat ini untuk bersatu atau berkonsolidasi melawan para oligarki. Muhammad Isnur selaku Ketua Bidang Advokasi Yayasan Lembaga Bantuan Hukum Indonesia (YLBHI) juga menambahkan bahwa saat ini terdapat fakta "saya punya data adanya kebijakan untuk mengirimkan para tentara dan polisi di berbagai perusahaan ... baik dengan cara penugasan maupun alih karyawan”. Isnur juga menambahkan sebagai contoh ada 11 tentara di tugaskan di PT. Arta Graha. Isnur juga menilai pidato Presiden Jokowi (14/7/2019) yang menyatakan penghambatan investasi bakal dikejar dan dihajar sebagai sebuah pernyataan deklaratif yang melindung oligarki.

Keterwakilan formal narasi politik hijau dalam pemerintahan merupakan salah satu faktor yang bisa membatasi ruang gerak oligarki. Keterwakilan yang dimaksud penulis adalah keterwakilan formal sebagai partai politik peserta pemilu. Terlepas seberapa besar legitimasi publik pada PHI atau sejauh mana PHI dapat mengagregasi kepentingan publik namun tidak dapat dipungkiri bahwa aktor pembuat keputusan adalah partai politik dan ketidakhadiran narasi politik hijau sebagai platform partai politik akan mengurangi substansi pertimbangan para pembuat keputusan terkait dampak kerusakan lingkungan. Karena pada faktanya klaim representasi politik non-elektoral sejauh ini melalui Walhi ataupun Greenpeace tidak cukup efektif dalam mempengaruhi pembuatan keputusan.

Pengalaman menarik disampaikan oleh Yayan Hidayat, Sekretaris Jendral Aliansi Masyarakat Adat Nusantara (AMAN). Menurutnya, tidak hanya sekedar perlu adanya partai politik alternatif, "kita bukan alternatif, tetapi kita justru adalah poros utama rakyat". Menurutnya, AMAN sejak 1999 atau secara resmi terlibat langsung pada tahun 2009 dalam elektoral, "kita sadar bahwa kita butuh keterwakilan" oleh karena itu menurutnya lewat Forum Tali Mandat, AMAN sering kali mengutus atau mengusung seseorang sebagai perwakilan. Pada tahun 2014 terdapat 36 anggota parlemen utusan AMAN, sedangkan pada tahun 2019 terdapat 34 anggota parlemen, "sampai sekarang mereka telah menghasilkan 75 


\section{Nakhoda: Jurnal Ilmu Pemerintahan \\ Vol. 19 No. 2 Tahun 2020 Halaman 151-167 \\ e-ISSN: 2656-5277 | p-ISSN: 1829-5827}

produk hukum dalam setiap level pemerintahan". Hal ini menjelaskan urgensitas kehadiran narasi politik hijau dalam keterwakilan politik di Indonesia. Namun di sisi lain, fenomena partai kartel yang menjangkit hampir seluruh partai politik yang ada sekarang membuat partai politik yang ada semakin jauh dari kepentingan publik (Katz \& Mair, 1995, 2009). Ditambah dengan keikutsertaan oligarki dalam mensponsori kandidat dan partai politik yang ada, maka sulit untuk berharap adanya pertimbangan dampak kerusakan lingkungan dalam setiap pembuatan keputusan.

Permasalahan lain dari ketidakhadiran PHI adalah pemilu, salah satu di antaranya Undang-Undang (UU) Nomor 2 Tahun 2011 Tentang Partai Politik merupakan upaya dari para oligarki untuk mempertahankan pendapatannya dari pihak-pihak yang mengancam dalam hal ini partai baru. Misalnya syarat pendirian partai politik harus terdapat di $100 \%$ provinsi, 75\% Kabupaten/kota dan 50\% kecamatan (Pasal 3). Selain itu pada UU tersebut batas maksimal sumbangan ke partai politik dalam 1 tahun adalah 7,5 Miliar, naik 3,5 Miliar dari UU Parpol tahun 2008. Selain sangat memberatkan, masalah lainnya adalah persyaratan itu hanya berlaku untuk partai baru, sedangkan tidak dengan partai lama, hal ini juga ditegaskan dalam Peraturan KPU (PKPU) Nomor 6 Tahun 2018. Artinya, setiap partai mesti memiliki basis massa dan modal yang kuat dan partai tanpa pemodal cenderung sulit untuk berkompetisi dan pada saat yang sama aturan yang diproporsional tersebut akan menguntungkan partai besar (Bachtiar et al., 2020).

Selain itu, Kaitan lain antara rekayasa pemilu dengan sistem kepartaian dijelaskan dengan detail melalui Hukum Duverger (Duverger Laws). Menurut Duverger (1972) terdapat efek mekanis dan efek psikologis dalam aturan-aturan pemilu. Efek mekanis menegaskan kurang terwakilinya partai ketiga (partai baru atau partai kecil) karena aturanaturan seperti ambang batas (threshold). Efek mekanis ini kemudian mempengaruhi para pemilih yang mendukung partai kecil/partai baru yang secara psikologis terdorong untuk tidak menyia-nyiakan suara mereka hingga pada akhirnya terpaksa memilih partai besar yang berpotensi lolos pemilu. Semenjak Reformasi 1998 sampai 2019 telah terjadi banyak perubahan sistem pemilu dari peningkatan ambang batas baik parliamentary threshold (dari 2,5\% tahun 2009, 3,5\% tahun 2014, dan 4\% tahun 2019) maupun presidential threshold (5\% tahun 2004, 15\% tahun 2009, $20 \%$ tahun 2014 dan 2019), perubahan sistem pemilihan tertutup menjadi terbuka, perubahan teknik perhitungan Kuota Hare menjadi Sainte Lague Murni, serta perubahan mekanisme pemilu terpisah menjadi serentak.

Senada dengan itu, menurut Dandhy Laksono dalam Twitternya (18 April 2019) menuliskan "ada Partai Hijau di Indonesia. Mereka gak sanggup jadi partai yang ikut pemilu karena syaratnya mahal, berat dan hampir tak masuk akal. Itu pun belum tentu lolos". Artinya hambatan pembentukan partai politik hijau tidak serta merta dihadapkan dengan keinginan atau kesadaran masyarakat (Muhammad \& Abraham, 2016) tetapi juga terdapat adanya pengaruh dari sistem (Duverger \& Duverger, 1972). Sejauh ini fokus utama penyelesaian masalah lingkungan sering kali dengan perspektif kekuasaan bukan representatif (keterwakilan). Misalnya dengan menciptakan sistem meritokrasi dalam institusi atau mendorong penegakkan hukum. Dalam beberapa kasus hal ini cukup efektif misalnya pada pertengahan November 2016 Mahkamah Agung (MA) memutuskan PT. Merbau Pelalawan Lestaru bersalah dan harus membayar ganti rugi sebesar Rp. 16.244.574.805,00 atas kerusakan lingkungan seluas 1.873 hektare. Namun, meski begitu banyak sekali gerakan masyarakat yang tidak berhasil mempengaruhi kebijakan politik, selain itu persoalan lingkungan sering kali tidak dapat selesai dengan penegakkan hukum sebagaimana sudah ditulis di atas. KPK sendiri mengidentifikasi setidak-tidaknya ada 6 cara: penyuapan, gratifikasi, konflik kepentingan, penyalahgunaan wewenang penyelenggara - pelaku usaha, memanipulasi data dan informasi, serta ketidakpatuhan dalam melaksanakan kewajiban. 


\section{Nakhoda: Jurnal IImu Pemerintahan \\ Vol. 19 No. 2 Tahun 2020 Halaman 151-167 \\ e-ISSN: 2656-5277 | p-ISSN: 1829-5827}

Ketidakefektifan kekuasaan dalam penyelesaian masalah lingkungan pada dasarnya karena setiap individu mementingkan diri sendiri dan kesadaran kolektif yang terimplementasi pada aturan dan kebijakan-kebijakan tentang penggunaan yang berkelanjutan pada dasarnya tidak akan banyak membantu (Hardin, 1968), bahkan tindakan altruistis atasnama kepentingan lingkungan kolektif menurut Mast (2013) akan merugikan individu yang altruistis dan menguntungkan bagi pesaingnya. Namun meski begitu tantangan terbesar justru bukanlah kepentingan individu tetapi ketidakseimbangan sistem politik yang menurut penulis dihasilkan dari ketidakhadiran narasi politik hijau dalam bentuk platform partai politik. Oleh karena itu narasi politik hijau masih memerlukan saluran formal politik untuk menegaskan eksistensinya. Hal yang sama juga berlaku untuk kelompok lain, misalnya studi Zainuddin dan Suryaningsih (2017) yang mendorong Hizbut Tahrir Indonesia (HTI) untuk bertransformasi menjadi partai politik seperti Ikhwanul Muslimin (IM) dalam rangka memperjuangkan kepentingan Islam dalam kehidupan bernegara. Lebih dari itu, kehadiran Partai Hijau di Indonesia justru berpotensi untuk membatasi ruang gerak oligarki dalam melakukan konsentrasi penguasaan sumber daya alam. Terlepas dari perdebatan atas legitimasi keterwakilan namun faktanya keterwakilan non-elektoral sampai saat ini masih dirasa kurang mampu mempengaruhi pembuatan keputusan. Dalam konteks ini, narasi politik hijau mesti bertransformasi dalam platform partai politik di Indonesia sehingga dapat secara langsung terlibat dan berpengaruh sebagai pertimbangan proses pembuatan kebijakan politik.

\section{Kesimpulan}

Analisa yang kerap kali digunakan dalam persoalan kerusakan lingkungan dan dampaknya seperti perspektif konstitusional dan institusional serta paradigmatis tidak banyak berpengaruh karena pada dasarnya tetap akan ada individu yang mencari keuntungan dengan mengeksploitasi sumber daya alam. Adapun gerakan partisipasi masyarakat terkait isu lingkungan jarang sekali berhasil mempengaruhi kebijakan politik. Nampak dominasi oligarki dalam konsentrasi sumber daya alam yang menyebabkan kerusakan lingkungan serta dampaknya terhadap kerugian negara dan ketimpangan yang terjadi di Indonesia. Fenomena tersebut senantiasa terjadi sepanjang sejarah di mana orangorang kaya akan terus berusaha mengakumulasi dan mempertahankan kekayaan serta pendapatannya. Lingkungan sebagai sumber daya alam pada dasarnya merupakan sumber pendapatan oligarki yang konsentrasi pengelolaan dan penguasaannya sering kali berdampak pada ketimpangan material, kerugian negara dan perilaku korupsi. Melalui keuntungan dari sumber daya alam itulah oligarki mampu dan senantiasa mempertahankan pendapatannya misalnya dengan menyewa profesional, mensponsori kandidat dalam pemilihan umum, mendirikan partai politik untuk mempengaruhi proses kebijakan bahkan sampai melakukan penyuapan.

Analisis yang lebih realis memiliki konsekuensi yang juga lebih realistis, yakni dibanding menuntut kesadaran kolektif dari para pejabat dan penegak hukum atau berharap adanya kerja sama antar negara dan antar lembaga, artikel ini justru menunjukkan urgensi dari perimbangan kekuasaan dan keterwakilan narasi politik hijau dalam bentuk platform partai politik untuk membatasi dan menghambat dominasi oligarki. Selain itu kegagalan partisipasi masyarakat juga disebabkan tidak adanya keterwakilan narasi politik hijau yang sampai saat ini tersebar di berbagai janji politik kandidat dan partai politik menjelang pemilihan umum. Namun alih-alih bertransformasi menjadi partai politik sebagaimana terjadi di negara lain di mana trennya terus mengalami peningkatan, transformasi narasi politik Hijau di Indonesia selain kurang mendapat dukungan dari masyarakat juga terhambat oleh pro-kontra internal, aturan-aturan pendirian partai dan mekanisme pemilihan umum. Kesadaran yang juga penting dan lebih mendesak selain kesadaran akan 


\section{Nakhoda: Jurnal Ilmu Pemerintahan \\ Vol. 19 No. 2 Tahun 2020 Halaman 151-167 \\ e-ISSN: 2656-5277 | p-ISSN: 1829-5827}

lingkungan adalah kesadaran akan keterwakilan lingkungan dalam sistem politik di Indonesia. Di samping itu, tuntutan kaum realis terkait pengawasan juga akan lebih efektif jika dilakukan oleh keterwakilan politik Hijau dalam bentuk partai politik dibanding sekedar menuntut perbaikan regulasi dan penegakkan hukum yang jauh lebih sulit ditengah-tengah dominasi oligarki dan kepentingan para politisi dalam mendapatkan sumber pendanaan untuk kontestasi pemilihan umum.

\section{Ucapan Terima Kasih}

Penulis sangat mengapresiasi dan berterima kasih kepada para narasumber maupun aktivis lingkungan yang senantiasa berjuang ditengah-tengah dominasi oligarki yang sangat kuat. Ungkapan terima kasih juga disampaikan kepada Riaty Raffiudin, Ph.D. sebagai pembimbing dalam penulisan artikel ini dan juga tesis penulis di Universitas Indonesia.

\section{Daftar Pustaka}

Arifin, Z. (2012). Politik Ekologi: Ramah Lingkungan Sebagai Pembenaran. Jurnal Ilmu Sosial Mamangan, 1(1), 11-16. https://doi.org/https://doi.org/10.22202/mamangan.88

Arnesen, S., \& Peters, Y. (2018). The Legitimacy of Representation: How Descriptive, Formal, and Responsiveness Representation Affect the Acceptability of Political Decisions. Comparative Political Studies. https://doi.org/10.1177/0010414017720702

Aspinall, E. (2014). Popular agency and interests in Indonesia's democratic transition and consolidation. In M. Ford \& T. B. Pepinsky (Eds.), Beyound Oligarch: Wealth, Power and Contemporary Indonesian Politics (pp. 117-13). Cornell Southeast Asia Program Publications. https://doi.org/10.5728/indonesia.96.0011

Aspinall, E., \& Barenschot, W. (2019). Democracy For Sale: Pemilihan Umum, Klientelisme dan Negara di Indonesia. Yayasan Pustaka Obor.

Azhar, M. A. (2007). Kerusakan Ekologis Hutan Jati di Kabupaten Muna (Potret Pemujaan Pendekatan Anthroposentris). Jurnal Ilmu Sosial Dan Ilmu Politik, 11(2), 153-286. https://doi.org/https://doi.org/10.22146/jsp.10998

Bachtiar, Bolqiah, L. H., \& Andrean, S. (2020). Menguatnya Partai Politik Kartel Pada Pemilu Serentak 2019. Jurnal Pengawasan Pemilu Provinsi DKI Jakarta, 73-92. ISSN: 2541-2078

Bayu, D. D. (2019). KPA: 364 Orang Jadi Korban Konflik Agraria Selama 2018. Katadata. https://katadata.co.id/hariwidowati/berita/5e9a5577d2e10/kpa-364-orang-jadi-korbankonflik-agraria-selama-2018

Botetzagias, I., \& van Schuur, W. (2012). Active Greens: An Analysis of the Determinants of Green Party Members' Activism in Environmental Movements. Environment and Behavior, 44(4), 509-544. https://doi.org/10.1177/0013916510393278

Bowman, J. S. (1978). Ecology and the Politics of Scarcity: Prologue to a Political Theory of the Steady State. William Ophuls. The Journal of Politics, 40(1), 249-250. https://doi.org/10.2307/2129995

Bryner, G. C. (2001). ABSTRACT: The Idea of Sustainability and its Implications for Energy Law and Policy. AAPG Bulletin, 85. https://doi.org/10.1306/61eed9a4-173e$11 \mathrm{~d} 7-8645000102 \mathrm{c} 1865 \mathrm{~d}$

CNN Indonesia. (2018). Total 326 Orang Jadi Tersangka Korupsi SDA Selama 2010-2017. https://www.cnnindonesia.com/nasional/20180427144107-20-294128/total-326orang-jadi-tersangka-korupsi-sda-selama-2010-2017

Dalton, R. J., Recchia, S., \& Rohrschneider, R. (2003). The environmental movement and the modes of political action. Comparative Political Studies, 36(7), 743-771. https://doi.org/10.1177/0010414003255108

Dethier, J. J. (2017). Trash, cities, and politics: Urban environmental problems in 
Indonesia. Southeast Asia Program Publications, 103, 73-90. https://doi.org/10.5728/indonesia.103.0073

Duverger, M., \& Duverger, M. (1972). The Forms of Political Conflict. In The Study of Politics. https://doi.org/10.1007/978-94-009-3171-8_6

Dwi, D. (2018). Jakarta dan Bandung dua kota dengan kualitas udara terburuk di Asia Tenggara. Antara Megapolitan. https://megapolitan.antaranews.com/berita/36759/jakarta-dan-bandung-dua-kotadengan-kualitas-udara-terburuk-di-asia-tenggara

Gahrton, P. (2015). Introduction: The Greens - Towards Hegemony in the Anthropocene. In P. Gahrton \& C. Lucas (Eds.), Green Parties, Green Future: From Local Groups to the International Stage. Pluto Press. http://www.jstor.org/stable/j.ctt183p8rr.6

García, J. H., Sterner, T., \& Afsah, S. (2007). Public disclosure of industrial pollution: The PROPER approach for Indonesia? Environment and Development Economics, 12(6), 739-756. https://doi.org/10.1017/S1355770X07003920

Greenpeace Indonesia. (2019). Ganti Rugi 18,9 Triliun Terkait Kasus Kebakaran dan Kerusakan Hutan Gagal Dibayar Sejumlah Perusahaan, Pemerintah Harus Mengambil Langkah Tegas. Siaran Pers Greenpeace. https://www.greenpeace.org/indonesia/siaran-pers/1103/ganti-rugi-189-triliun-terkaitkasus-kebakaran-dan-kerusakan-hutan-gagal-dibayar-sejumlah-perusahaanpemerintah-harus-mengambil-langkah-tegas/

Hadiz, V. R., \& Robison, R. (2013). The political economy of oligarchy and the reorganization of power in Indonesia. Indonesia. https://doi.org/10.5728/indonesia.96.0033

Hardin, G. (1968). The tragedy of the commons. Science, 162, 1243-1248. https://doi.org/10.1126/science.162.3859.1243

Hartati, A. Y. (2007). Lingkungan Hidup dan Liberalisasi Perdagangan: Upaya Mencari Jalan Tengah. Jurnal Ilmu Sosial Dan Ilmu Politik, 11(2), 193-208. https://doi.org/https://doi.org/10.22146/jsp.10996

Hikmat, I., Durohman, I., \& Bhawono, A. (2016). Kisah "Perjanjian Preman" Ahok. Detik. https://news.detik.com/x/detail/investigasi/20160530/Deal-Reklamasi-di-PulauHengky/

Jingga, S. R., \& Lestari, A. F. (2019). Oligarki Hambat Perlindungan Lingkungan. Harian Nasional. http://www.harnas.co/2019/10/25/oligarki-hambat-perlindungan-lingkungan

Kasmiruddin. (2018). 102 Juta Kendaraan Ikut Cemari Udara, Polygon Galakkan Bersepeda Mendukung Environment Indonesia Menjadi Lebih Baik. Babel Review. https://babelreview.co.id/102-juta-kendaraan-ikut-cemari-udara-polygon-galakkanbersepeda-mendukung-environment-indonesia-menjadi-lebih-baik

Katz, R. S., \& Mair, P. (1995). Changing models of party organization and party democracy: The Emergence of the Cartel Party. Party Politics, 1(1), 5-28. https://doi.org/10.1177/1354068895001001001

Katz, R. S., \& Mair, P. (2009). The cartel party thesis: A restatement. Perspectives on Politics, 7(4), 753-766. https://doi.org/10.1017/S1537592709991782

Khotami. (2020). Institutional Building Dalam Mengatasi Persoalan Pertambangan Emas Tanpa Izin Di Kabupaten Kuantan Singingi Provinsi Riau. Nakhoda: Jurnal Ilmu Pemerintahan, 19(1), 17-37. https://doi.org/10.35967/jipn.v19i1.7842

Kompas. (2016). Setiap Tahun, Hutan Indonesia Hilang 684.000 Hektar. Kompas. https://regional.kompas.com/read/2016/08/30/15362721/setiap.tahun.hutan.indonesia. hilang.684.000.hektar

KPK RI. (2019). Nota Sintesis : Evaluasi Gerakan Nasional Penyelamatan Sumber Daya Alam 2018. https://www.kpk.go.id/images/pdf/LITBANG/Nota-Sintesis-Evaluasi- 
GNPSDA-KPK-2018-Final.pdf

Kusno, A. (2011). The green governmentality in an Indonesian metropolis. Singapore Journal of Tropical Geography, 32(3), 314-331. https://doi.org/10.1111/j.14679493.2011.00440.x

Lay, C. (2007). Nilai Strategis Isu Lingkungan dalam Politik Indonesia. Jurnal Ilmu Sosial Dan Ilmu Politik, 11(2), 153-286. https://doi.org/https://doi.org/10.22146/jsp.10994

Ma'mun, A. R., \& Kosandi, M. (2020). The Politics of Campaign Funding in The Presidential Election 2019. Literatus, 2(2), 162-180. https://doi.org/https://doi.org/10.37010/lit.v2i2.93

Mast, J. (2013). Politik Lingkungan Internasional. In J. T. Ishiyama \& M. Breuning (Eds.), Ilmu Politik dalam Paradigma Abad ke-21 (1st ed.). PT Kharisma Putra Utama.

Mietzner, M. (2014). Oligarchs, Politicians, and Activists: Contesting Party Politics in Post-Suharto Indonesia. In Beyond Oligarchy: Wealth, Power and Contemporary Indonesian Politics (pp. 99-116). Cornel Southeast Asia Program Publications. https://doi.org/10.7591/9781501719158-008

Muhammad, J., \& Abraham, D. (2016). Lengan Politik Masyarakat Sipil: Pengalaman. Harian Indoprogress. https://indoprogress.com/2016/10/lengan-politik-masyarakatsipil-pengalaman-dan-ikhtiar-partai-hijau-indonesia/

Mutia, E. F., \& Asteria, D. (2018). Jakarta Bay reclamation policy: An analysis of political ecology. E3S Web of Conferences. https://doi.org/10.1051/e3sconf/20185200014

Naess, A. (1973). The Shallow and the Deep, Long-Range Ecology Movement: A Summary. Inquiry (United Kingdom), 16(1-4), 95-100. https://doi.org/10.1080/00201747308601682

Nomura, K. (2007). Democratisation and environmental non-governmental organisations in Indonesia. Journal of Contemporary Asia, 37(4), 495-517. https://doi.org/10.1080/00472330701546566

Nooteboom, G., \& De Jong, E. B. P. (2010). Against "Green Development Fantasies": Resource degradation and the lack of community resistance in the Middle Mahakam Wetlands, East Kalimantan, Indonesia. Asian Journal of Social Science, 38(2), 258 278. https://doi.org/10.1163/156853110X490935

Pratiwi, O. C. (2007). Banjir Jakarta 2007: Kegagalan Kolektif Pengelolaan Bumi. Jurnal Ilmu Sosial Dan Ilmu Politik, 11(2), 153-286. https://doi.org/10.22146/jsp.10999

Pulido, L., \& Merchant, C. (1993). Radical Ecology: The Search for a Livable World. Economic Geography, 69(4), 445. https://doi.org/10.2307/143605

Qodriyatun, S. N. (2008). Isu Lingkungan dalam Pilkada13-18. Info Singkat Pusat Penelitian Badan Keahlian DPR RI, 4(2), 13-18. https://berkas.dpr.go.id/puslit/files/info_singkat/Info Singkat-X-2-II-P3DI-Januari2018-189.pdf

Robison, R., \& Hadiz, V. R. (2004). Theories of Change and The Case of Indonesia. In Reorganising Power in Indonesia: The Politics of Oligarchy in an Age of Markets (pp. 18-39). Routledge. https://doi.org/10.4324/9780203401453_chapter_1

Shohibuddin, M. (2016). Peluang dan Tantangan Undang-undang Desa dalam Upaya Demokratisasi Tata Kelola Sumber Daya Alam Desa: Perspektif Agraria Kritis. Masyarakat: Jurnal Sosiologi, 21(1), 1-33. https://doi.org/10.7454/mjs.v21i1.5021

Siombo, M. R. (2014). Tanggung Jawab Pemda Terhadap Kerusakan Lingkungan Hidup Kaitannya Dengan Kewenangan Perizinan Di Bidang Kehutanan Dan Pertambangan. Jurnal Dinamika Hukum, 14(3), 394-405. https://doi.org/10.20884/1.jdh.2014.14.3.306

Sugiarto, N. K. (2018). Bisnis Militer Pasca Orde Baru. CosmoGov, 4(2), 237-246. https://doi.org/10.24198/cosmogov.v4i2.17064 
Susanti, N., \& Afrizal, A. (2018). Upaya Greeanpeace Menjaga Kawasan Pantai Indonesia Terkait Proyek Pulau Reklamasi Teluk Jakarta. Jurnal Online Mahasiswa Fakultas Ilmu Sosial Dan Ilmu Politik Universitas Riau, 5(1), 1-18. ISSN: 2355-6919.

Swainson, L., \& Mahanty, S. (2018). Green economy meets political economy: Lessons from the "Aceh Green" initiative, Indonesia. Global Environmental Change, 53, 286295. https://doi.org/10.1016/j.gloenvcha.2018.10.009

Syarif, M. L., \& Faisal. (2019). Addressing the Root of Political Corruption in Indonesia. Jurnal Antikorupsi Integritas, 5(2), 191-198. https://doi.org/https://doi.org/10.32697/integritas.v5i2.487

Tolo, E. Y. S. (2014). Public Participation in the Implementation of Forestry Decentralization in Indonesia. Bisnis \& Birokrasi Journal, 20(2), 113-120. https://doi.org/10.20476/jbb.v20i2.3065

Transparency International. (2013). Corruption Perceptions Index 2013 - Results. Transparency.Org.

VOA Indonesia. (2019). Partai Hijau di Jerman, Perancis, Inggris Rayakan Perolehan Besar dalam Pemilu Eropa. VOA Indonesia. https://www.voaindonesia.com/a/partaihijau-di-jerman-perancis-inggris-rayakan-perolehan-besar-dalam-pemilueropa/4934167.html

Wapner, P. (1995). Politics beyond the state Environmental Activism and World Civic Politics. World Politics, 47(3), 311-340. https://doi.org/10.1017/S0043887100016415

Widjojanto, B. (2017). Masa Depan Indonesia dikorupsi: Tantangan Pengelolaan Sumber Daya Alam. In Penguasaan Sumber Daya Alam dalam Cengkraman Oligarki dan Rezim Neoliberal (11th ed., pp. 8-45). Intrans Institute.

Winarno, H. H. (2016). Adhie Massardi: Ahok kongkalikong dengan pengembang tumbangkan Rizal. https://www.merdeka.com/peristiwa/adhie-massardi-ahokkongkalikong-dengan-pengembang-tumbangkan-rizal.html

Winters, J. A. (2011). Oligarchy. Cambridge University Press. https://doi.org/10.1017/CBO9780511793806

Yenrizal, \& Izomiddin. (2017). Strategi Komunikasi Politik Berbasis Isu Lingkungan Pada Pemilihan Umum Kepala Daerah Palembang 2018. Pelaksanaan Pilkada Serentak Yang Sehat, Jujur, Adil Dan Akuntabel, 1-19. http://repository.umrah.ac.id/74/1/strategi komunikasi politik berbasis isu lingkungan pada pemilihan umum kepala daerah palembang 2018.pdf

Yusri, A., \& Adlin. (2017). Organisasi Masyarakat Sipil Membela Masyarakat Dalam Kasus Kabut Asap Di Pekanbaru Tahun 2014. Jurnal Ilmu Pemerintahan Nakhoda, 16(28), 17-37. https://doi.org/10.35967/jipn.v16i28.5820

Zainuddin, M., \& Suryaningsih. (2017). Rekalkulasi Transformasi Kelompok Penekan Menjadi Partai Politik: Kajian Pada Hizbut Tahrir Indonesia. Jurnal Ilmu Pemerintahan Nakhoda, 16(28), 1-6. https://doi.org/10.35967/jipn.v16i28.5828 